\author{
Davor Lazić \\ Joce Laloševića 1, RS-25101 Sombor \\ a0814252@unet.univie.ac.at
}

\title{
Joker između estetizacije i politizacije resantimana
}

\begin{abstract}
Sažetak
Radom se želi razumjeti velika popularnost filma Joker redatelja Todda Phillipsa iz 2019 godine. Film i figura Jokera interpretirana je u okviru filozofije, odnosno estetike i politike resantimana. Rad nudi zaključak da film i figura Jokera ponavljaju osjećaj nejednakosti, kao jedno rašireno osjećanje u svijetu, između njegove estetizacije i politizacije.

\section{Ključne riječi}

Joker, bol, resantiman, estetizacija, politizacija
\end{abstract}

»(Tvoj) Bijes je dar! «1

\section{Uvod}

Colin Crouch 2005. objavljuje knjigu Postdemokracija u kojoj dijagnosticira duboku krizu demokracije. Knjiga biva ubrzo prevođena na više jezika (njemački 2008.; srpski 2018.) i postaje nezaobilazna u razumijevanju suvremenog trenutka. Na dužnost predsjednika Sjedinjenih Američkih Država 2017. godine stupa Donald Trump. Lažne vijesti bivaju riječ iste te 2017. godine. Godine 2013. Thomas Piketty objavljuje djelo Kapital u 21. stoljeću. Branko Milanović 2016. godine izdaje knjigu Globalna nejednakost. Obje knjige svjedoče o velikoj i rastućoj nejednakosti u svijetu. Dolazak velikog broja izbjeglica s Bliskog istoka u Europu, počevši od 2014. godine, prati i porast ksenofobije i islamofobije u Europskim državama. Britanci se 2016. većinski opredjeljuju za Brexit. Sirom Europe događa se uspon nacionalističkih i antiliberalnih partija poput AFD-a u Nemačkoj, Front Nationala u Francuskoj ili FPÖ-a u Austriji. Etabliraju se autoritarne vođe poput Recepa Tayyipa Erdoğana u Turskoj, Viktora Orbána u Mađarskoj, Lecha Kaczyńskog u Poljskoj, Aleksandra Vučića u Srbiji. Cijeli ovaj proces imenovat će se velikom regresijom. ${ }^{2}$ Pojavljuju se talasanja i na ljevici, poput uspona Sirize u Grčkoj, Corbyna unutar Laburista u Velikoj Britaniji, Sandersove trke za predsjedničkog kandidata demokrata u Sjedinjenim Američkim Državama. Protesti su širom svijeta. U ovakvom se svijetu 2019. godine pojavljuje film Joker u režiji Todda Phillipsa.

Rage Against the Machine, »Freedom«, u: Rage Against the Machine, Rage Against the Machine, Epic, 1992. Ovaj rad posvećujem Josipu Peiću (1985. - 2015.), doktorandu na Europskom sveučilišnom institutu u Firenci, sugovorniku i prijatelju.
2

Usp. Heinrich Geiselberger, Die Große Regression. Eine Internationale Debatte über die geistige Situation der Zeit, Suhrkamp, Berlin 2017. 
Film Joker prvog je vikenda prikazivanja u Sjedinjenim Američkim Državama zaradio blizu 100 milijuna dolara. Time je zaradio gotovo dvostruko više nego što je u njega samoga bilo uloženo (oko 60 milijuna dolara). Bio je nominiran za 11 nagrada Oscar, od čega je dobio dvije. ${ }^{3}$ Ipak, da riječ nije samo o američkom snu ili košmaru nego da je riječ i o globalnom fenomenu pokazuje i podatak da je Joker »najgledaniji strani film u Srbiji svih vremena«. ${ }^{4}$ Film je pokrenuo lavinu rasprava, ali i rijeku članaka. Joker je jedan od onih filmova koji ne ostavljaju ravnodušnim i koji naprosto tjeraju na to da se zauzme pozicija u odnosu na njega i u odnosu na (be)smisao koji nudi.

Veliča li taj film nasilje, od negativca pravi heroja, te je time svojevrsni nagovor na nasilje, uništavanje? Je li film svojim veličanjem nasilja i moralna prijetnja (pa barem i u vidu malograđanskog morala)? ${ }^{5}$ Warner Bros. Entertainment Inc., izdavač filma Joker, morao je odgovoriti s »Ne.«. ${ }^{6}$ No, kako biti uvjeren ovim »Ne.« kada se nasilje dogodilo tijekom projekcije filma Uspon mračnog viteza (The Dark Knight Rises, red. Christopher Nolan, 2012.) u jednom kinu u Aurori, u američkoj državi Colorado, gdje je dvanaest ljudi stradalo. Ne podupire li sam ovaj događaj u kinu tezu da film potiče nasilje? Je li nemoguće praktično se držati u linijama podjele na stvarnost i fikciju? Bi li za Arthura trebalo imati više razumijevanja zbog njegova traumatizirana djetinjstva? Je li film do te mjere subverzivan da je nužno čak i da se policija umiješa i zauzme svoju poziciju? Tako nešto dogodilo se u Grčkoj, gdje je film zabranjen za mlađe od 18 godina, gdje su revnosni službenici alarmirali policiju, zahtijevajući da se mladi udalje iz kina, što je naizgled jedan od rijetkih slučajeva kada se ova zakonska regulativa striktno poštovala. ${ }^{7}$ To je tek jedan isječak od mnogih pitanja koja je pokrenuo film.

\section{Između filozofije i filma}

Osnovna je ideja rada ponuditi jedno tumačenje onoga što su gledaoci vidjeli, osjetili i doživjeli. Predmet je analize film Joker u režiji Todda Phillipsa iz 2019. godine, ali u perspektivi filozofije (estetizacije i politizacije) resantimana. Na ovom mjestu svjesno biram perspektivizam kao jednu epistemološku poziciju. Takva jedna pozicija polazi od različitih filozofskih autora, ali pokazuje se i na samoj stvari. Stvar nam se uvijek pokazuje u određenoj perspektivi, u određenom smislu, u određenom profilu, u određenom sjenčanju, nijansiranju nje same. Sama stvar neiscrpna je u svom perspektivizmu, u svom bogatstvu smisla, u svojim profilacijama, sjenčanjima i nijansiranjima. Izbor za samu perspektivu predstavlja jedan složen proces, koji podrazumijeva različite političke, ekonomske, socijalne, kulturne i psihološke okolnosti u kojima se izražavamo. Što znači izabrati jednu određenu perspektivu i stati iza nje može se razumjeti tek iz cjeline smisla, odnosno tek u suodnosu s drugim perspektivama, kao drugim pretendentima na tumačenje stvari. ${ }^{8}$

Dva ključna alata preuzeta iz povijesti filozofije koja nam služe u razumijevanju kako filma Joker i figure Jokera tako i živca vremena koji je pogodio nalaze se u pojmovima resantimana i estetizacije politike. Popularizaciju pojma i jedno obuhvatnije značenje pojma resantimana možemo zahvaliti, prije svih, Friedrichu Nietzscheu, dok imenovanje jednog modernog fenomena estetizacijom politike dugujemo Walteru Benjaminu. Ovi pojmovi nisu preuzeti proizvoljno iz povijesti filozofije, kako bi onda imali ulogu Prokrustove postelje za Jokera. Oni su odabrani na osnovu određenih aspekata filma Joker i figure Jokera. 
Tri su aspekta resantimana najvidljivija u figuri Jokera dugotrajna patnja, kompenzacija kroz uobrazilju i želja za osvetom (zbog patnje). Osnova za interpretaciju Jokera kao figure resantimana dana je u njegovoj ekranizaciji kao čovjeka koji duboko pati. Patnja je zajednička Jokeru i resantimanu. Kasnije osnove za razumijevanja Jokera kroz figuru resantimana jesu epizode u kojima on bol kompenzira kroz imaginacije koje mu omogućavaju nastaviti dalje živjeti i ne izvršiti samoubojstvo, što je također zajedničko s resantimanom koji stvarnost falsificira ne bi li u njoj i s njom mogao živjeti. Zajednička im je volja za život ta koja pobjeđuje nad pamćenjem i nauštrb pamćenja. Pamćenje se uznosi volji za život. Zajednička osnova Jokera i resantimana dana je i u zajedničkoj želji za osvetom zbog nanijete boli, koja je vidljivija od strane javnosti koja podržava Jokera kroz jasne poruke poput Pobijte bogataše (Kill the Rich).

Estetizacija politike pojam je koji koristi Walter Benjamin i kojim opisuje fašizam. Estetizacija politike jedan je složen moderni fenomen i označava jedan specifičan hibridni pojam. Modernost predstavlja jedan širok, a možda i neiscrpan pojam, ali na ovom je mjestu dovoljno navesti u kontekstu umjetnosti i estetike da on predstavlja proces osamostaljivanja i diferenciranja estetike i umjetnosti u odnosu na druga područja ljudske djelatnosti, prije svega, u odnosu na religiju i politiku. Proces osamostaljivanja estetike dio je onoga što bismo mogli nazvati procesom modernosti. Estetika, među ostalim, zadobiva autoreferentni karakter, čiji je radikalni izraz larpurlatizam u umjetnosti. Estetizacija politike podrazumijeva da u tom kontekstu politika dobiva elemente estetike. Politika u tom smislu zadobiva estetske karakteristike jer se oblikuje kao umjetničko djelo i kao takva postaje jednim dijelom autoreferentna djelatnost, lišena njene sveprožimajuće uloge u društvu, kao i političke odgovornosti, morala i tradicije. Elemente estetizacije politike nalazimo i u figuri Jokera. Njegovu društvenu poziciju i njegovu patnju uzrokovanu njegovim porijeklom, neprilagođenošću, lošim uvjetima života, slabom društvenom i političkom podrškom, vidimo kroz jednu političku slijepu mrlju koja meandrira između psihologije i estetike. Putevi koji vode iz nezavidnog položaja u kojem se našao Arthur Fleck putevi su estetizacije patnje, dok politizacija njegova lika ima krajnje rubnu poziciju.

Podaci preuzeti iz baze Internet Movie Database. Dostupno na: https://www.imdb.com/ title/tt7286456/ (pristupljeno 1. 3. 2020.).

Usp. I. T., »'Džoker' najgledaniji strani film u Srbiji , Danas (25. 11. 2019.). Dostupno na: https://www.danas.rs/kultura/dzoker-najgledaniji-strani-film-u-srbiji/ (pristupljeno 1. 3. 2020.)

Usp. Dina Kapaeva, »Džoker ubojstvo čini ponovo velikim«, Danas (19. 11. 2019.). Dostupno na: https://www.danas.rs/svet/ dzoker-ubojstvo-cini-ponovo-velikim/ (pristupljeno 1. 3. 2020.).

Usp. Beta, »Vorner bros: Džoker nije predstavljen kao heroj«, Danas (25. 9. 2019.).
Dostupno na: https://www.danas.rs/kultura/ vorner-bros-dzoker-nije-predstavljen-kao-heroj/ (pristupljeno 1. 3. 2020.).

Usp. Beta/AFP, »Grčka policija izvela maloletnike iz bioskopa koji prikazuju 'Džokera' «, Danas (21. 10. 2019.). Dostupno na: https:// www.danas.rs/svet/grcka-policija-izvela-maloletnike-iz-bioskopa-koji-prikazuju-dzokera/ (pristupljeno 1.3. 2020.).

8

S druge strane, sam Joker daje osnovu za perspektivizam jer je on kao karta takva karta koja mijenja svaku drugu kartu. On nema naglašeno supstancijalno određenje. Stoga je u figuru Jokera već upisan svojevrsni perspektivizam. 
Često se, ako ne i uvijek, u osnovnom opisu filma navodi da je to psihološki triler, ${ }^{9}$ čime se vrši usmjeravanje naše intencionalne strukture u jedno određeno polje razumijevanja. Ukoliko bi slijedili ovo usmjerenje, utoliko bismo figuru Jokera mogli vidjeti kao osobu s gelastičnom epilepsijom. ${ }^{10}$ Problem je psihologizacije lika Jokera taj da se on prevodi u jednu psihološku kategoriju koja je lišena konteksta, najprije onog društvenog i političkog - tako se njegovo ponašanje tumači unutar jednog uskog polja psihologije; tako mu se oduzima politički i subverzivni potencijal, on se naturalizira i neutralizira. Joker kao lik postaje produkt svoje majke i samog sebe. Zatvoren u jedno tako usko polje artikulacije, biva potpuno sabotiran u svojoj ukupnoj moći.

\section{Od bola i patnje u svijetu k njihovoj artikulaciji}

Osnovna je teza da figura Jokera ekranizira jedno od centralnih osjećanja suvremenosti koje pojmimo pod imenom resantimana. Kretanje Jokera kao figure resantimana odvija se između njegove estetizacije i politizacije. ${ }^{11} \mathrm{Sa}-$ žetak figure resantimana između njegove estetizacije i politizacije dan je u prijelomnoj izjavi Arthura Flecka:

»Mislio sam da je moj život tragedija, ali sada shvaćam da je jebena komedija. $\ll^{12}$

Nietzsche u Genealogiji morala zastupa tezu da resantiman nastaje s ustankom robova u moralu. Zastupam tezu da ustanak u moralu ima svoju pretpovijest u vidu ustanka u estetici. Ovaj ustanak u estetici pokazujem na samom primjeru Nietzschea i njegova ranog djela Rođenje tragedije, pisanog pod utjecajem Schopenhauerova učenja i Wagnera. Poslije uvodne rasprave o pojmu resantimana, izlaže se estetizacija boli i patnje, kao pretpovijest resantimana, dana u ranom Nietzscheovu djelu koju prati izlaganje pojma estetizacije u Benjaminovu spisu o umjetničkom djelu. Slijedi izlaganje i rasprava s kasnim Nietzscheovim djelom u kojem je dana jedna kritika moralizacije resantimana i jedan nagovještaj politizacije resantimana. Slijedi rasprava o pojmu resantimana, kako je on dan kod Schelera, gdje se sučeljavaju različite perspektive u pogledu resantimana. U zaključnom djelu sažimam dvije perspektive u jednu - estetizaciju i politizaciju resantimana priključujem samom sadržaju filma.

\subsection{Osnovne crte pojma resantimana}

U ovdašnjem političkom diskursu resantiman nije riječ koja se često može čuti i koja je prihvaćena, za razliku od svakodnevice drugih jezičkih sredina. ${ }^{13}$ Njeno porijeklo jest strano, ali strano je bilo i Nijemcima do Nietzschea, tako da to nije razlog za njeno rijetko pojavljivanje. Češce se pojam resantimana, iako često neutraliziran, pojavljuje u akademskim krugovima, koji su po prirodi stvari upućeni na pojmove iz cjelokupne europske idejne baštine. Razloge za siromaštvo ovdašnjeg svakodnevnog političkog diskursa treba tražiti, prije svega, u sistematskom miniranju istog koji se neprestano događa s povremenim diskontinuitetima i vremensko-prostornim nišama u kojima se uviđao značaj njegovanja političkog polja, a ne njegovih opstrukcija. Češće se njegovao politički diskurs koji je paradoksalno ne samo apolitičan nego je, štoviše, i antipolitičan. Svrha je njegova da se društvo, koje svakako nije poznato po snazi javnosti i demokratičnosti, nikada i ne približi polju političke moći da odlučuje o sebi, već da se političko polje ovakvim diskursom sabotira, očisti od političkog te da se politika ne vodi javno, već zakulisno, odnosno 
$\mathrm{u}$ analogiji s dvorskom politikom prošlih vremena (mada, sam je ovaj termin dvorske politike jedno drveno željezo).

Resantiman je riječ francuskog porijekla za koju se tvrdi da je idiom i da ne postoji zamjenska riječ u drugim jezicima. ${ }^{14}$ Svoje porijeklo duguje francuskom glagolu ressentir iz kojega je imenica izvedena u 16. stoljeću. Glagol označuje ne sadržaj osjećanja, nego način osjećanja, odnosno dugotrajno djelovanje određenih osjećanja i njihov obnavljajući karakter. Doslovan prijevod glagola ressentir bi bio ponovo osjećati. Ipak, da osjećanja, koja se kriju iza ove riječi, nisu strana ni nefrancuzima potvrđuje izvoz ovog pojma i njegova afirmacija u drugim jezičkim sredinama, a pogotovo u njemačkom govornom području, gdje ovaj izraz živi novi život kroz veliku popularnost i rastuću upotrebu pojma do današnjih dana. Pored tvrdnje o idiomatskoj prirodi ovog izraza često se ipak ressentiment prevodi na njemački jezik s heimlicher Groll. Osjećanja najpribližnija osjećanju resantimana osjećanja su poput mržnje, ljutnje, srdžbe ili gnjeva. Pored toga, ovaj bi osjećaj karakterizirala, s jedne strane, dugotrajnost, dok bi, s druge strane, taj osjećaj bio često pritajen, čak nesvjestan.

Ono što je potrebno naglasiti kao bitnu karakteristiku ovog izvorno francuskog osjećanja i izraza jest njegova repetitivnost. Zanimljivost je da u prvobitnoj francuskoj upotrebi (npr. Molièrea) ovaj izraz nema isključivo negativnu konotaciju, već neutralnu, čak i pozitivnu. Tako bi on označavao i osjećanje zahvalnosti, kao ponavljanje osjećanja koje je izazvao događaj zbog kojega osjećamo zahvalnost, ali i jedno osvetničko osjećanje, kao ponavljanje osjećanja koje je izazvao događaj zbog kojega osjećamo želju za osvetom ili makar bol. Ali zašto se resantiman održao uglavnom u svojoj negativnoj konotaciji? U eseju o resantimanu, Scheleru će potpuno izvan vida ostati bilo koje

9

Usp. Jochen Kürten, »Psycho-Thriller 'Joker' führt mit elf Oscar-Nominierungen«, Deutsche Welle (13. 1. 2020.). Dostupno na: https://p.dw.com/p/3W8dE (pristupljeno 1. 3 . 2020.).

10

Lora Plit, »Džoker: Koja bolest se krije iza nekontrolisanog smeha Batmanovog neprijatelja«, BBC News (19. 11. 2019.) Dostupno na: https:/www.bbc.com/serbian/lat/svet50465753 (pristupljeno 1. 3. 2020.)

11

Estetizacija i politizacija ne znače da je bol oko koje se konstituira resantiman prvobitno neestetička i nepolitička. Termini estetizacije i politizacije imenuju dva načina upravljanja $\mathrm{s}$ boli, s različitim akcentuacijama. U kasnijim poglavljima bit će jasnije značenje toga, a naročito u posljednjem poglavlju koje se bavi pitanjem političke razlike.

12

Tragedija i komedija jedne su od najstarijih žanrova Europske umjetnosti. U antičkoj Grčkoj tijekom dionizijskih svetkovina pored tragedija održavale su se i komedije. Tragedije imaju radikalni karakter, one nam pokazuju svijet u njegovoj grozoti, kao svijet u kojem je život gotovo pa nemoguć, njihov je efekt svojevrsno odmicanje od svijeta. S druge strane komedije imaju više umirujući karakter, one nas uvlače u svijet, omogućavaju nam da živimo u svijetu i sa svijetom.

13

Usp. Christian Ernst Weißgerber, »Die neue Lust am Ressentiment. Grundzüge eines affekttheoretischen Ressentiment-Begriffs«, u: Rainer Mühlhoff, Anja Breljak, Jan Slaby (ur.), Affekt Macht Netz-Auf dem Weg zu einer Sozialtheorie der Digitalen Gesellschaft Transcript, Bielefeld 2019., str. 225-244; Stefan Dolgert, » The praise of ressentiment. Or, how I learned to stop worrying and love Donald Trump«, New Political Science 38 (2016) 3, str. 354-370, doi: https://doi.org/10. 1080/07393148.2016.1189030.

14

Peter Probst, »Ressentiment«, u: Joachim Ritter, Karlfried Gründer, Gottfried Gabriel (ur.), Historisches Wörterbuch der Philosophie, sv. 8, Schwabe, Basel 1992., str. 920924, str. 920 . 
drugo značenje osim negativnog. ${ }^{15}$ Probstovo objašnjenje je da resantiman, ukupno uzevši, označava prije osjećanja negativnog, a ne pozitivnog sadržaja jer su negativna osjećanja dugovječnija. ${ }^{16}$ Naše jezičko iskustvo i osjećanje koje se nadovezuje na ovu francusko-njemačku peripetiju jest situacija u kojoj primjećujemo da netko odlično pamti, za koga onda tvrdimo da pamti kao zlopamtilo. Zaključno možemo reći da pojam resantimana imenuje jedno pretežno negativno osjećanje koje karakterizira dugotrajnost, prikrivenost $\mathrm{i}$ repetitivnost.

\subsection{Bol i patnja kao tragička spoznaja i njihov korelat $u$ vidu tragičke umjetnosti}

Iako se pojam pojavljuje prvobitno u eseju Michela de Montaignea, Nietzsche daje kako najuvjerljiviju, tako i najprecizniju obradu osjećanja i pojma resantimana. Ona je evidentno pokrenuta djelom Vrijednost života (Der Werth des Lebens) Eugena Dühringa, danas prilično zaboravljenog, a tada prilično popularnog filozofskog pisca. ${ }^{17}$ Najuspješniju razradu i upotrebu pojma resantimana nalazimo u Nietzscheovu djelu Genealogija morala, naročito u njegovoj prvoj raspravi, djelu koje je naročito zaslužno za popularizaciju ovog pojma. Da bismo bolje razumjeli pojam resantimana ipak je dobro uključiti i pojam tragičke spoznaje i njezina korelata tragičke umjetnosti iz Nietzscheova ranog spisa Rođenje tragedije, koji stoji pod jakim utjecajem Schopenhauerova djela i bliskosti s Richardom Wagnerom. ${ }^{18}$

Što je zapravo tragička spoznaja i kakvu ono ulogu ima u konstituciji resantimana? Za tragediju u njemačkom jeziku koriste se dva termina, jedan je grčka pozajmljenica tragedija (Tragödie), koja označava pjesmu satira, dok je druga žalobna igra (Trauerspiel). Tragička spoznaja i njen umjetnički korelat čine dva uvida. Prvi uvid jest uvid u bol i patnju koju iskušavamo u svijetu. Za ovo osjećanje nalazimo i izraz prabol (Urschmerz), ${ }^{19}$ čime se očigledno želi naglasiti ontološki status patnje u svijetu, njena neizostavnost i stalnost. Drugi se uvid događa kao uzdizanje patnje, kao spoznaja da i pored patnje i bola život zaslužuje da se živi, te jedno opravdanje te iste patnje. Ovdje se miješaju dvije perspektive, jedna antička, druga kršćanska, od kojih svaka nudi i određeno rješenje. Ovo je put koji slijedi Schopenhauer u djelu Svijet kao volja i predodžba, ali i Nietzsche u ranom djelu Rođenje tragedije.

U Svijetu kao volji i predodžbi, tragička je spoznaja uvid u »stravičnu stranu života«. ${ }^{20}$ Slijedeći Kantovu treću kritiku i njegovo razlikovanje lijepog i uzvišenog, u tragediji se vidi jedan oblik uzvišene umjetnosti. Kao što je uzvišeno jedno kroz nezadovoljstvo posredovano zadovoljstvo, odnosno negativno zadovoljstvo, ${ }^{21}$ tako je i ono tragično jedno zadovoljstvo posredovano nezadovoljstvom. Tragička nas umjetnost odmiče od onoga što jesmo pod pretpostavkama principa individuacije, vremena, prostora i kauzalnosti. Ovo odmicanje kao efekt tragičke umjetnosti donosi nam uvid u uzaludnost voljnih akata, koji su izvor nepresušne patnje, koje omogućava barem kratkotrajno oslobođenje od istih. U tragediji se egzemplarno odvija borba volje sa samom sobom. Stoga ona ima i svojevrsnu propedeutičku funkciju u pogledu poricanja volje. ${ }^{22}$

Rođenje tragedije će nam tragičku spoznaju približiti kroz poznati mit o satiru, odnosno silenu, pratiocu Dionisa. Kralj Mida je dugo i bezuspješno tražio satira po šumi. Konačno, kada ga je uhvatio, upitao ga je što bi za ljude bilo najbolje i najsavršenije. Satir prvobitno odbija odgovoriti na pitanje, a kada krene odgovarati, prvo naglašava da je neznanje bolje za njega, a potom mu 
priopćava da je najbolje da se nije ni rodio, a kada već jest da bi mu bilo bolje da što prije umre. Imaginarna borba protiv ove spoznaje $\mathrm{i} »$ preokretanje satirske mudrosti« odvija se u lijepoj umjetnosti, koja je korelat užasa života. Znanje užasa preobražava se u iluziju umjetnosti koja čini život podnošljivim, koja čini život življivim i životnim. Jedno lukavstvo života koje se zbilo. ${ }^{23}$

Schopenhauer i rani Nietzsche oblikuju u svojim djelima nešto što se može nazvati umjetničkom religijom ili estetičkom metafizikom. Riječ je o jednoj vrsti estetizacije patnje kojom daju smisao istoj. Ujedno je to i odgovor na staro pitanje o teodiceji, odnosno na pitanje o tome zašto bog dopušta patnju u svijetu. Za razliku od teološkog ili moralnog opravdanja (Rechtfertigung) boga, svijeta i života, oni su u svojim djelima ponudili jedno estetičko, odnosno umjetničko opravdanje patnje.

Teze Oda Marquarda iz njegove znamenite zbirke eseja Estetika i anestetika vide premještanje patnje iz domene morala i religije u domenu estetike također kao proces modernizacije. ${ }^{24}$ Estetika i estetizacija imaju, takoreći, kompenzacijsku ulogu u procesu modernizacije kao procesu raščaravanja svijeta jer one unutar estetičke domene pokušavaju održati ovu začaranost svijeta unutar svijeta koji se mijenja. Drugu stranu ovoga procesa Walter Benjamin vidjet će kao proces atrofije aure umjetničkog djela. ${ }^{25}$

\section{5}

Usp. Maks Šeler [Max Scheler], »Resantiman u izgradnji morala«, u: Maks Šeler [Max Scheler], Eseji iz fenomenološke antropologije, prevela Aleksandra Kostić, Fedon, Beograd 2011., str. 127-289, str. 130.

16

P. Probst, »Ressentiment«, str. 921.

17

Usp. Aldo Venturelli, »Asketismus und Wille zur Macht. Nietzsches Auseinandersetzung mit Eugen Dühring«, u: Aldo Venturelli, Kunst, Wissenschaft und Geschichte bei Nietzsche, De Gruyter, Berlin, New York 2003., str. 203-237.

18

Usp. Reg DŽ. Holingdejl [Reginald John Hollingdale], Niče. Život $i$ filozofija, preveo Rastko Jovanović, Dereta, Beograd 2004.

\section{9}

Friedrich Nietzsche, Die Geburt Der Tragödie, u: Friedrich Nietzsche, Sämtliche Werke. Kritische Studienausgabe in 15 Einzelbänden, sv. 1, Die Geburt der Tragödie. Unzeitgemäße Betrachtungen 1-4. Nachgelassene Schriften 1870-1873, Deutscher Taschenbuch Verlag, München, Berlin 1988., str. 39.

20

Arthur Schopenhauer, Die Welt als Wille und Vorstellung, sv. 1, Diogenes, Zürich 1977., str. 318.
21

Immanuel Kant, Kritik der Urteilskraft, Suhrkamp, Berlin 2014., § 27.

22

Usp. Günter Zöller, »Ästhetische Welt- und Willenserkenntnis. Schopenhauers Kunst- und Musikphilosophie im dritten Buch der Welt als Wille und Vorstellung«, u: Oliver Hallich, Matthias Koßler (ur.), Arthur Schopenhauer: die Welt als Wille und Vorstellung, Akademie, Berlin 2014., str. 119-136, str. 129.

23

Usp. F. Nietzsche, Die Geburt der Tragödie, str. 34-38.

24

Usp. Odo Marquard, »Aesthetica und Anaesthica. Auch als Einleitung«, u: Odo Marquard, Aesthetica und Anaesthetica: Philosophische Überlegungen, Wilhelm Fink Verlag, München 2003., str. 11-20. U ovom periodu identičnu ulogu pripisuje estetici i Koepnick u studiji u kojoj razrađuje Benjaminovu tezu o estetizaciji politike. Usp. Lutz Koepnick, Walter Benjamin and the Aesthetics of Power, University of Nebraska Press, Lincoln 1999. str. $29 \mathrm{i} \mathrm{d}$

25

Usp. Walter Benjamin, Das Kunstwerk im Zeitalter seiner technischen Reproduzierbarkeit mit Ergänzungen aus der ersten und zweiten Fassung, Reclam, Stuttgart 2011. 


\subsection{Kriza auratske umjetnosti i estetizacija politike}

Dijelom od strane Nietzschea potaknuta estetizacija jedan će svoj produžetak imati u Marinettijevu Manifestu futurizma - prototipu estetizacije fašizma za Waltera Benjamina u njegovu eseju o umjetničkom djelu. Estetizacija politike je, po Benjaminovu spisu o umjetničkom djelu, proces koji svoje porijeklo ima u suvremenoj deauratizaciji umjetnosti kroz tehničku reprodukciju umjetničkog djela koji jedan svoj zaokret ima u hibridnom spoju umjetnosti i politike. Njime se u politici naglašava prvenstveno njen izraz.

Benjamin će u tzv. spisu o umjetničkom djelu (Kunstwerk-Aufsatz) porijeklo umjetnosti vidjeti u religioznoj umjetnosti, odnosno u ritualu. Za takvo ritualno porijeklo umjetnosti opredijelit će pojam aure. Auratsko umjetničko djelo ima svoje mjesto, svoju upotrebu kao i upotrebnu vrijednost unutar rituala. Auru Benjamin, pomalo misteriozno, definira kao »jedinstveno pojavljivanje daljine, koliko god može biti bliska «. ${ }^{26}$ Aura označava enigmatično, a opet izvjesno približavanje daljine. Njome se naprosto imenuje određeni ključni elemenat magijskog, ritualnog, odnosno, koncem religioznog iskustva. Specifičnost je auratske umjetnosti njeno pružanje u jedinstvenom ovdje i sada, odnosno u njenoj vezanosti za konkretno vrijeme i prostor rituala. Njegova produkcija, percepcija, kao i komunikacija stoje u neposrednoj vezi.

S druge strane, moderno će vrijeme donijeti tehničke inovacije, prije svega, u pogledu novih medija poput filma i fotografije, koje će ujedno donijeti promjenu u pogledu značenja umjetničkog djela. Tako u samom naslovu spisa stoji da je za razumijevanje modernog vremena i umjetnosti tog vremena ključna reproduktivnost (umjetničkog djela). S tehničkim inovacijama u umjetnosti koje omogućavaju beskonačno ponavljanje umjetničkog djela, nauštrb tradicionalnog umjetničkog djela koje je neponovljivo, zavisno od konteksta i uklopljeno u određeni svijet rituala, zbiva se propadanje auratskog karaktera umjetnosti. Neponovljivost ritualnog vremena i prostora karakteristična za auratsku umjetnost biva u određenoj mjeri isključena tehničkim promjenama koje omogućavaju beskonačno ponavljanje (reprodukciju) modernog umjetničkog djela. Ovakva tehnička promjena nije izvanjska umjetnosti i nije puko formalna, nego se ona upisuje i u samu strukturu (iskustva) umjetničkog djela. S obzirom na oslobođene mogućnosti ponavljanja umjetničkog djela, umjetnost postaje masovna. Njena se vrijednost iz upotrebne vrijednosti (Gebrauchswert), koju posjeduje u tradicionalnoj ritualnoj umjetnosti, transformira dijelom u izložbenu vrijednost (Ausstellungswert), koja je najvidljivija $\mathrm{u}$ modernim umjetnostima filma i fotografije. ${ }^{27}$

Tako ritualno obezglavljena umjetnost svoje novo utemeljenje i svoju novu upotrebu i u upotrebnu vrijednost nalazi dijelom i u politici. Na drugoj su strani tendencije koje pokušavaju umjetnosti dati utemeljenje u samoj umjetnosti, kao umjetnost za volju same umjetnosti, odnosno - l'art pour l'art. Benjamin će ovakve tendencije ponegdje imenovati i teologijom umjetnosti. ${ }^{28}$ Jednu tendenciju ovakvog hibridnog spajanja umjetnosti i politike Benjamin će imenovati estetizacijom politike. Estetizacija politike proces je u kojem politika gubi, takoreći, svoju upotrebnu vrijednost nauštrb izložbene vrijednosti. Na primjeru se Marinettija i njegova Manifesta to pokazuje u estetizaciji rata, koji ima efekt zamagljivanja ostalih aspekata rata. Tako i estetizacija politike kroz masovne skupove, uniforme, marširanja, kult vođe, Olimpijske igre 1936. godine, masovni turizam u organizaciji nacističkog režima (Kraft durch Freude), medijsku djelatnost Leni Riefenstahl, naglašava estetički aspekt politike, dok njegov pravni, ekonomski, etički aspekt zamagljuje. U zajednici 
koja je s modernim dobom izgubila vezivno tkivo koju je pružala predmodernost, estetika u ovom slučaju dobiva ulogu reintegracije te zajednice i to na vlastitim (estetičkim) osnovama.

\subsection{Resantiman genealogije morala}

Obrada resantimana u Nietzscheovu kasnom spisu predstavlja novu obradu tragičkog. Temi tragičkog ponovno je pristupljeno, ali u novoj perspektivi, na novi način i s novim posljedicama. U svojoj osnovi rasprava također ima bol i patnju. S druge strane, upravljanje bolom i patnjom ne vodi k tragičkoj umjetnosti i ne ulijeva se u nju, nego ima bitno drugačiji efekt.

Resantiman ima središnju poziciju unutar kasnih rasprava, čiji je osnovni smjer tema porijekla moralnih predrasuda, odnosno pitanje o izvoru dobra $i$ zla, a koja je ujedno i kritika Schopenhauerova učenja negiranja života, te time djelomično i samokritika, ali i rasprava s engleskim psiholozima, njihovom poviješću i genealogijom morala i njihovim njemačkim zastupnikom u vidu djela Izvor moralnih osjećanja Paula Réea. ${ }^{29}$

Ključne su karakteristike učenja o resantimanu Genealogije morala sljedeće:

1. nemoć, spriječenost akcije (bol, patnja);

2. reaktivnost;

3. imaginarna osveta;

4. specifični stvaralački kapaciteti i to u vidu stvaranja vrijednosti (dobro - zlo, djelatnik odvojen od djelanja, smisao u poniženosti).

Pojam resantimana pojavljuje se najprije $\mathrm{u} 10$. paragrafu prve rasprave i $\mathrm{s}$ njim se konceptualizira kritika u prethodnim paragrafima, u kojima je govor bio o »engleskim psiholozima«, »dobru« i »zlu«, »svećenicima«, »narodu svećenika«, »Izraelu«. Resantiman i njegov stvaralački karakter pojavljuju se ujedno s postavkom ustanka robova u moralu. ${ }^{30}$ Resantiman je ime za one koji su lišeni moći, za one koje su deprivilegirani, za one koje su nedjelatni i kojima je uskraćena i sama mogućnost participacije u djelatnom polju. Ipak, ustanak $u$ moralu događa se kada resantiman, usprkos nemoći, deprivilegiranosti, usprkos uskraćenosti mogućnosti učešća u djelatnom polju, postane stvaralački. Stvaralački karakter resantimana izrasta iz njegove pozicije, u kojoj mu je djelatnost u pravom smislu uskraćena, gdje se iz nemoći rađa želja za osvetom. Želja za osvetom, kao plod djelatne uskraćenosti, ne ispunjava se direktno, kao napad na one moći koje su uzroci pozicije resantimana, kojima se osvećujemo za nanesenu bol, gdje se mogućom pobjedom nad istim osnažujemo, oslobađamo, gdje se zadobivaju djelatne moći i djelatno polje, nego se odvija sublimno, odnosno kao uzdizanje (Sublime, das Erhabene), kao jedna imaginarna osveta. Resantiman se ne oblikuje iz vlastite moći tako

\section{6}

Ibid., str. 19.

27

Ibid., str. 22 i d.

28

Ibid., str. 20.

29

Usp. Friedrich Nietzsche, Zur Genealogie der Moral, u: Friedrich Nietzsche, Sämtliche
Werke, Kritische Studienausgabe in 15 Einzelbänden, sv. 5, Deutscher Taschenbuch Verlag, München - Berlin 2012., str. 245-412, str. 247-256.

30

Ibid., str. 270 
što se direktno izvanjštava, nego se tek u suprotstavljanju onome izvanjštenome, onome drugome, onome što nije on sam, konstituira kroz takav u osnovi negativni ili reaktivni stvaralački akt. Njegova se reaktivnost ogleda u njegovoj potrebi za onim, čemu se on sam suprotstavlja, u potrebi za jednim svijetom prema kojem se odnosi naspram i nasuprot, i u čijem se odnosu tek sukonstituira. Isti način slijedi resantiman i u konceptualizaciji onoga što je »dobro« i onoga što je »loše« postupkom via negativa. Odnosno, loši su oni kojima je podčinjen, oni koje resantiman trpi, oni koji su djelatni, moćni i privilegirani. Na osnovi konceptualizacije loših, tek povratno resantiman koncipira ono dobro i u tom dobru sebe samog. Resantiman ipak na kraju trijumfira na jedan podzeman način. ${ }^{31}$

Konceptualizacija resantimana genealogije morala daleko je uspješnija od onoga što je suprotno istome. To su oni koji su plemeniti, otmjeni (die Vornehmen). Oni koji su plemeniti djeluju spontano i naprosto su djelatni. Ipak, nezamislivo je da se netko razvija iz samog sebe, bez ikakvog poticaja sa strane. Sam razvoj ljudske jedinke uvjetovan je izvanjskim podražajima na koje se odgovara i u čijem se odgovaranju raste i razvija jedinka. Veliki dio onoga što znamo $i$ što jesmo, naučili smo od drugih, pokrenuti drugima, potaknuti drugima. Da nije tako, pitanje je što bismo postali. Primjer je za to tzv. fenomen »divlje djece«. Naziv divlja djeca označava djecu koja su slijedom različitih okolnosti odrastala izolirana od ljudske zajednice, često u divljini sa životinjama, a potom su vraćena u ljudsku zajednicu. Takvoj djeci nedostaju osnovne ljudske karakteristike koje se stječu u zajednici i sva odreda morala su ih učiti. S druge strane, takva djeca svjedoče i čine očiglednim da se čovjek tek jednim dijelom rađa, a većim dijelom postaje. I drugi primjeri iz psihologije, antropologije, medicine, govore u prilog tezi da se život kojemu su uskraćena iskustva, poticaji, podražaji ne obogaćuje, ne razvija, ne raste pravilno.

Postoje i elementi svojevrsne naturalizacije u ovom postupku. Oni koji su djelatni, privilegirani, plemeniti nisu to iz razloga društveno-povijesnog oblikovanja, nego su oni sami po sebi takvi, po prirodi. Tako da su oni plemeniti ne zbog uvjeta koje imaju kao privilegirana klasa, naspram deprivilegirane, nego su oni sami od sebe takvi. Na drugom se mjestu opovijesnjuje ovaj sukob i tumači kao sukob dvije povijesne perspektive. Plemenita perspektiva dobar - loš pripisuje se Rimu i Rimljanima, dok perspektiva resantimana dobar - zao Judeji i Židovima, ali i reformaciji i Francuskoj revoluciji. U ovim se obrisima vidi problematičnost teza o onima koji su »plemeniti«. U njihovim prednostima ne vide se privilegirani uvjeti koji su im omogućili da se pojave kao takvi, nego se porijeklo njihove »plemenitosti« naturalizira, odnosno ideologizira.

U obranu genealogije morala, kada je riječ o postupku naturalizacije plemenitih, govori činjenica da je ipak djelatnost, činjenje posljednji kriterij i da iza djelanja ne postoje nikakvi subjekti iz kojih slijedi određeno djelanje, gdje bi iz plemenitih slijedilo plemenito djelanje. Ne, djelanje razlučuje tko je tko. Nietzscheovim riječima:

»Ali nema takvog supstrata, nema nikakvog 'bitka' iza djelanja, djelovanja, postajanja; 'djelatnik' je puka izmišljotina pridodana djelanju - djelovanje je sve. (32 $^{32}$

Odvajanje djelatnika od djelatnosti je, slijedeći Genealogiju morala, izum resantimana. S druge strane, time se ipak zamagljuju uvjeti mogućnosti djelatnosti. Ako je samo djelatnost posljednji kriterij, onda nam se lako događa da 
ne uvidimo da oni koji su nedjelatni i koji se nisu izborili za polje djelatnosti, upravo iz razloga uvjeta (ne)mogućnosti djelatnosti, gdje im je onemogućeno iz različitih razloga participirati u moći. Iz razloga što su siromašni, žena, stranac, Rom ili neka druga 'tradicionalno' deprivilegirana pozicija.

\subsection{Građanski resantiman i njegovo prevladavanje kroz, kršćansku ljubav}

U eseju o resantimanu, Scheler uglavnom ponavlja zapažanja koja nalazimo već kod Nietzschea, ali i ranije kod Montaignea i Dühringa. Schelerov je doprinos specifično naglašavanje određenih elemenata pojma, kao i specifično usmjerenje koje mu daje. Doprinos je njegova eseja pojmu resantimana u naglašavanju ideje jednakosti u konstituciji resantimana. Specifično je usmjerenje koje Scheler daje pojmu resantimana emancipacija kršćanskog morala od resantimana i njegovo isključivo vezivanje za građanski moral. Opisujući osjećanje resantimana kao »doživljajnu cjelinu«, Scheler mu pridaje karakteristiku dugotrajnosti, a uzrok dugotrajnosti ovog negativnog osjećanja vidi, prije svega, u nemogućnosti svojevrsnog rasterećenja, odnosno nemogućnosti direktne osvete, koju smatra »najznačajnijim izvorom« istog. Nemoć da se osveta izvrši vodi k svojevrsnoj fantaziji o osveti i k stvaranju određenih vrijednosnih iluzija i odgovarajućih vrijednosnih sudova. ${ }^{33}$

Osnova da bi se resantiman ispoljio ideja je jednakosti, i kako će to kasnije biti razvijeno u tekstu kao uspoređivanje vlastite vrijednosti s vrijednostima drugih. Tamo gdje postoji pretpostavka nejednakosti veličina, gdje postoji ideja da se nije jednak s onim drugim, gdje je razlika ne relativna, nego apsolutna, tu se resantiman ne razvija. ${ }^{34} \mathrm{Tu}$ ideju Scheler ne prati dalje, ali je dobro ukazati na perspektive u kojima se javlja ideja jednakosti. Ideja jednakosti je moderna ideja. Uvjet da se resantiman javi u povijesnom je smislu modernost. Bez modernosti, pod ovom pretpostavkom, nema ni resantimana. Resantiman se, stoga, ispoljava pod pretpostavkama demokracije, pravne jednakosti, ekonomske i društvene meritokracije. Pretpostavka demokracije je da postoji ideja političke jednakosti, odnosno jednakog učešća u političkoj zajednici, jednake participacije u upravljanju istom, odlukama vezanim za istu, kao i osmišljavanju iste. Ideja pravne jednakosti je pretpostavka jednakosti u formalno-pravnom smislu. Pretpostavka društvene i ekonomske meritokracije je ideja da ljudi na osnovi svojih vlastitih zasluga, odnosno osobnih talenata, rada, pregalaštva stječu kako ekonomska dobra, tako i društvene pozicije. Društvena i ekonomska meritokracija pretpostavlja jednakost pristupa različitim dobrima, kao i željenim društvenim pozicijama. U diskrepanciji koja se javlja između ideje jednakosti (prava) i faktičke moći pojedinaca ili kolektiva vidi se osnova za nastanak resantimana.

Prema ukidanju ili barem ublažavanju resantimana vode dva puta. Jedan je predmoderni, gdje ne postoji naglašeno ideja jednakosti, nego ljudi prihvaćaju svoje mjesto unutar određenog poretka, unutar svog staleža ili svoje kaste. Ne usporede se s onima u odnosu na koje su supstancijalno nejednaki, nego u najboljem slučaju s onima unutar svojeg staleža, kaste, esnafa, gilde. Drugi

Ibid., str. 272-273.

32

F. Nietzsche, Zur Genealogie der Moral, str. 279 .
33

Usp. M. Šeler [M. Scheler], »Resantiman u izgradnji morala $\ll$, str. $132 \mathrm{i}$ d.

34

Ibid., str. 138 . 
je put, put realizacije moderne pretpostavke jednakosti. Eseju $»$ Resantiman $u$ izgradnji morala« blizak je prvi put, dok potpuno ostaje slijep za drugi (egalitaristički) put. ${ }^{35}$

Kako napadajući resantiman, napada jednakost gdje god se ona pojavi, tako Scheler kritiku kapitalizma preokreće u kritiku upravo njegovih emancipatorskih mogućnosti. Tako je njegova kritika usmjerena na modernu mogućnost da se bez obzira na porijeklo, na neko prirodno stanje, putem zalaganja i bogaćenja, dolaska do ekonomskih moći, ostvari društvena pozicija. Tržište i novac kroz vlastito sljepilo za tradicionalne privilegije vrše naizgled svojevrsno ujednačavanje svih. ${ }^{36} \mathrm{U}$ tome se i ogleda njegova kritika štrebera, skorojevića. ${ }^{37}$ Nazvati nekog skorojevićem, štreberom govori i o poziciji onoga tko imenuje. Za onoga tko imenuje on nije ispravan jer ne posjeduje porijeklo jer je self-made man, kako je preko Atlantika, nasuprot ovome kritičkom značenju, ova figura idealizirana.

Schelerova kritika resantimana usmjerena je na modernističku komponentu jednakosti i otvara prostor normalizacije nejednakosti i apologije određene privilegirane klase. ${ }^{38}$ Problem je ovakve kritike u tome što ona podrazumijeva prirodne dispozicije određenih, da očigledno vladaju drugima, da nad njima imaju moć. U naturalizaciji je i ideologizaciji ovih prirodno privilegiranih slijepa mrlja njegove kritike jednakosti resantimana. Ako prihvatimo da ljudi nisu jednaki, nije nam namjera da nejednakost ljudi naturaliziramo ili ideologiziramo i tu se vidi pozicija privilegiranog, odnosno slijepa mrlja iz koje filozof govori.

Moderni zahtjev za jednakošću, koji je snažno potvrđen događajem Francuske revolucije, odgovor je na raširene nejednakosti predmodernog svijeta. Koje se rješenje nudi u eseju o resantimanu? Resantiman se dovodi na prag političkog, ali se potom suspendira u povratku na teologiju, odnosno depolitizacijom kroz kršćansku ljubav. Za prevladavanje resantimana nudi se teološko rešenje u njegovu dokidanju kroz kršćansku ljubav, a ne njegovo moguće političko obuzdavanje u vidu emancipirajućih, egalitarnih politika. Njegova je strategija i unutar shvaćanja samog kršćanstva naglašavanje kršćanskog personalizma nauštrb kršćanskog socijalizma. Boreći se protiv ideje jednakosti, svim se silama Scheler trudi pokazati je kao izvanjsku »izvornom kršćanstvu«. Tako da kršćanstvu za sve suprotstavlja kršćanstvo odabranih i to pokušava učvrstiti kroz više primjera. Scheler se pokazuje u ovom eseju kao ljubitelj jasnih opozicija. ${ }^{39}$

Srednje rešenje odnosa između privilegiranih i deprivilegiranih i pojave resantimana, koje se prije može naslutiti čitanjem eseja, nego što je to eksplicitno dano, jest izvjesno darivanje bogatih siromašnima. Schelerov je odgovor u najblažem smislu normalizujući u pogledu nejednakosti, a zaoštreno je to odgovor antimodernista koji fantazira o romantiziranom jasno hijerarhiziranom predmodernom svijetu, stare (malo)građanštine koja gubi privilegije, protivnika demokracije i političkog svijeta naprosto. ${ }^{40}$ Suprotstavljanje ideji jednakosti mjesto je koje vjerojatno sve antimodernističke tendencije gaje i koje na svom hijerarhiziranom nebu ne mogu inkorporirati. U tome se i ogleda radikalnost ideje jednakosti.

\section{Pitanje političke razlike}

U ovome zaključnom poglavlju nam je bitno pokazati politike resantimana u suvremenom kontekstu i njihovu estetizaciju i politizaciju kroz lika Jokera 
u filmu Joker. Tako prvo pokazujemo politike resantimana kao one koje se nalaze unutar liberalnog političkog polja, ali i one koje se nalaze na obodu tog polja. Zatim uvodimo kriterij razlikovanja estetizacije politike i politizacije estetike. Zaključno dajemo odgovor na pitanje velike popularnosti Jokera ona se nalazi u raširenom osjećanju nejednakosti koju je film ekranizirao.

Arthur Fleck čovjek je koji pati. Uzrok njegova bola i patnje nije više u tragičkoj pogrešci ( $\dot{\alpha} \mu \alpha \rho \tau i ́ \alpha){ }^{41}$ Ona je u samoj njegovoj poziciji kao onoga koji trpi bol. Ekranizira se jedna konstitucija čovjeka oko boli. Već prvi kadrovi nagovještavaju to. Klaun koji honorarno radi u šoping zoni pokušavajući privući mušterije tablom s natpisom everything must go. Isuviše jasna aluzija na vrijeme u kojem živimo. Ne više nonšalantnost ranijeg liberalizma s everything goes nego sada već i kao zapovijed. Ne samo da sve ide nego sve i mora ići. Potom, Arthur završava na zemlji namagarčen i prebijen od strane lokalnih vjetrogonja. Dok klaun leži na zemlji pokušavajući doći do daha, kamera se udaljava i na ekranu se ispisuju velika žuta slova - Joker. Bol i patnja koju Arthur osjeća cjelinom filma nisu dani supstancijalno, nego medijalno. Bol i odnošenje spram iste, koje je dano prije kao jedan proces boli, ujedno nam

35

Prevoditeljica je na ovom mjestu posegla za pojmom buržuja i ovaj pojam prevela s buržoaski moral. Bürger je naprosto građanin i ne vidi se razlog zašto bi se pojam die bürgerliche Moral preveo s jednim, pomalo i arhaičnim pojmom buržoaskog morala. O neuvažavanju distinkcije u prevođenju termina Bürger i Bourgeois svjedoče i potonje stranice eseja (usp. Max Scheler, »Das Ressentiment im Aufbau der Moralen«, u: Max Scheler, Vom Umsturz der Werte. Abhandlungen und Aufsätze, Der Neue Geist-Verlag, Leipzig 1919., str. 183). Polazišna bi točka motivacije srpskog prijevoda mogla biti kod nas uvriježena kovanica francuska buržoaska revolucija. Ono što smatram neadekvatnim jest guranje pojma $u$ povijest, odnosno postupak pomoću kojega bi se pojam isključivo vezivao za jedan određeni povijesni kontekst. Ovdje nadasve nije riječ o tome, nego je riječ o jednoj klasi koja je pobijedila, čije su vrijednosti pobijedile, čiji se moral proširio i čije se vrijednosti baštine $\mathrm{i}$ dan danas. Prijevodom pojma Bürger s građanin željelo se izbjeći svojevrsno povijesno zamrzavanje i izborom se termina pokušala pokazati relevantnost pojma i eseja kako za početak 20. stoljeća (esej o resantimanu prvi se put pojavio 1912. godine, a potom 1915. u zbirci rasprava $O$ prevratu vrijednosti - Vom Umsturz der Werte), tako i za današnjicu. Ipak, kada kršćanstvo trijumfira nad poganstvom (kao u poznatoj sintagmi philosophia ancilla theologiae) ili građanstvo nad Ancien Régimeom ne događa se da moć pobijeđenog potpuno iščezne, nego ona nastavlja živjeti usporedno s drugim moćima, ali kao podčinjena novim odnosima moći

36

Naravno da to nije uvijek i u svim periodima nastanka kapitalizma i da od polaznih osnova uvelike zavisi društvena pozicija pojedinca, kako je o samoreprodukciji elita davno pisao Wright Mills u svojoj knjizi o elitama. Usp. Rajt Mils [Charles Wright Mills], Elita vlasti, preveo Ratoljub D. Dodić, Plato, Beograd 1998.

37

Usp. M. Scheler, »Das Ressentiment im Aufbau der Moralen«, str. 67. Za izvrstan prijevod knjige, koji dugujemo Aleksandri Kostić potpuno nezahvalan posao bilo je prevođenje ovog njemačkog pojma Streber, koji je prevela s našim pojmom skorojević.

38

Usp. M. Šeler [M. Scheler], »Resantiman u izgradnji morala«, str. 139.

39

Ibid., str. $177 \mathrm{i} \mathrm{d}$

40

Ovakve antimodernističke ideje nisu strane našoj suvremenosti i nisu društveni obod, čak u suvremenim postdemokratskim društvima imaju pretenzije postati politički mainstream. O tome svjedoči slučaj organizacije Nacionalne avangarde koja preuzima ideju arheofuturizma Guillaumea Fayea, a čijim događajima prisustvuju predsjednica vlade i predsjednik Srbije. Usp. K. R., »Zašto 'Nacionalna avangarda'?«, Danas (8. 10. 2018.). Dostupno na: https://www.danas.rs/drustvo/zasto-nacionalna-avangarda/ (pristupljeno 1. 3. 2020.); Rastislav Dinić, »Arheofuturizam«, Peščanik (13. 10. 2018.). Dostupno na: https://pescanik.net/arheofuturizam/ (pristupljeno 10. 3. 2020.).

41

Usp. Aristotel, Poet. 1452b-1453a. 
svjedoči o samoj poziciji u kojoj se Arthur, ali i drugi nalaze. Bol nam govori tko smo i gdje se nalazimo. Bol tumači svijet. ${ }^{42}$ Ali ne samo da nam tumači svijet u nekom ontološkom ili hermeneutičkom smislu nego i dalje, u političkom smislu. Na osnovi boli koju trpimo razumijemo sebe i svoju poziciju u političkom svijetu. Naša bol nije samo naša nego je i dio jedne zajedničke boli koje nas povezuje s onima koji tu istu bol podnose. ${ }^{43}$

Problematična je strana procesa boli kada se ona transformira u ono što Scheler naziva resantimanskom kritikom koja svoje porijeklo ima u figuri svećenika Genealogije morala ${ }^{44}$ Resantimanska kritika vrsta je kritike koja nema za cilj kritikom ukazati na pogreške i probleme koji bi potom bili otklonjeni. Resantimanska kritika stalno proizvodi svoj predmet kritike i to je način na koji se ona reproducira, obnavlja, održava i čime mobilizira svoje snage. Njen cilj nije uklanjanje predmeta koji kritizira jer bi to uklonilo i nju samu, nego stalna perpetuacija kritike i njenog predmeta. Na isti način na koji svećenik mora reproducirati grešnost i ujedno nemoć da se grešnosti umakne, tako i politički narativ stalno mora reproducirati političku opasnost ili političkog suparnika/neprijatelja, također kao svoj predmet kritike. Sam taj predmet kritike kao takav često je ne samo neotklonjiv nego on i mora biti takav da bi se resantiman reproducirao.

Zajednice boli koje su se formirale unutar suvremenog političkog okvira, kao okvira igre između slobode i jednakosti, predstavljaju različite politike resantimana kao politike identiteta. Njihova se pozicija ogleda u (djelomičnoj ili potpunoj) isključenosti iz političkog polja, odnosno patnje i nemoći na osnovu koje paradoksalno formiraju svoj politički identitet (žene, homoseksualci, različite manjinske grupe). Dok na osnovi političke razlike formiraju svoj identitet, njihov politički ideal, referent i mjesto priznanja srednjoklasna je pozicija unutar postojećih okvira. S druge strane, politike resantimana moraju stalno reproducirati svoju patnju i isključenost da bi na taj način održale politiku identiteta. Uklanjanje patnje i isključenosti uklonilo bi i njihov politički identitet zasnovan na resantimanu. Ovakvi zahtjevi za jednakost i politike koje ga sprovode rađaju resantiman na drugoj strani u formi neokonzervativnog sentimenta uperenog protiv identitetskih politika, odnosno protiv jednakosti i države (blagostanja) koja je redistribuira ${ }^{45}$ Razlika između resantimana politika identiteta unutar liberalnog poretka i resantimana neokonzervativnih politika identiteta je da prve djeluju i propulzivne su unutar postojećih okvira, dok druge naizgled dovode u pitanje sam taj poredak nauštrb jednakosti. S druge strane, resantiman radikalno egalitarnih politika također dovodi u pitanje postojeći politički okvir, ali ovaj u pravcu veće jednakosti.

Profil resantimana Arthura Flecka pokreće se s ubojstvima koje počini u podzemnoj željeznici. Ona su okidač za ovaj novi sloj značenja koja dobiva njegova figura. Komentar na televiziji Thomasa Waynea otkriva nam da su žrtve bili njegovi zaposlenici s Wallstreeta i uz to dobri, pristojni i obrazovani, dok on u ubojici vidi nekoga tko ubija iz zavisti, s motivima klasne mržnje. S druge strane, njegov sugovornik nam otkriva postojanje resantimanske javnosti, odnosno građana koji su bili zle sreće (less fortunate residents) i koji, nošeni osjećanjem klasne mržnje (anti-rich sentiment) nalaze čak i simpatije za ubojicu. Arthur Fleck je netko tko bol i patnju prevladava kroz imaginaciju, dok resantimanska javnost na njega projicira ulogu osvetnika. Lice klauna postaje simbol protesta deprivilegiranih s nedvosmislenom porukom - pobijte bogataše (Kill the Rich). 
Pri kraju eseja o umjetničkom djelu, Benjamin će naznačiti jedan fenomen koji je relevantan i danas, estetizaciju politike. ${ }^{46}$ Uvođenje ovog termina u kontekstu naše teme ima za cilj i svojevrsno sumiranje naše rasprave. Konstitucija resantimana vodila je od ishodišne boli $\mathrm{k}$ njenom uzdizanju u jedan vid imaginarne osvete. Teza je koju zastupamo ta da je termin estetizacije politike svojevrstan odjek filozofije resantimana i njome dajemo dosadašnjoj raspravi završni sloj. ${ }^{47}$

Estetizacija politike podrazumijeva određeno upravljanje kojim se određena osjećanja usmjeravaju i reduciraju na određen estetički oblik. Ne znači to da ova osjećanja gube potpuno svoju političku moć i politički značaj, ali ona bivaju potisnuta ili uzdignuta i prevladana kroz određen estetički oblik. Politički karakter ovih osjećanja ne iščezava, nego nastavlja živjeti podčinjen estetizaciji istih. Benjamin u svome vremenu ovakav način upravljanja osjećanjima estetizacijom politike vidi u fašizmu. Njemu on suprotstavlja politizaciju estetike i komunizam. S politizacijom estetike i komunizmom ne napušta se polje upravljanja osjećanjima, njihovom estetizacijom i politizacijom. Ono što predstavlja političku razliku jest uvećanje prava. Uvećanje prava je točka razlikovanja učinaka estetizacije politike i politizacije estetike. Pregnantno izraženo riječima Gernota Böhmea:

»Izraz umjesto prava! To je zamjena [Ersetzung] politike putem estetike. $\aleph^{48}$

Ukoliko osjećanja svoj konačni oblik nalaze samo u jednom estetičkom izra$\mathrm{zu}$, a ne u konačnici u uvećanju političkih prava, ekonomskih dobara ili u pravnim kodifikacijama, utoliko konkretno upravljanje ima za cilj neutralizaciju tih osjećanja kroz njihovu transformaciju i održavanje postojećeg odnosa moći. Usmjeravanje tih osjećanja može voditi ne samo u smjeru koji se ne podudara s njihovim prvobitnim motivacijama i koji se ne podudara s uvećanjem njihovih prava i moći nego čak potpuno suprotno i nauštrb njima.

Svaka estetička forma koja ima namjeru političkog angažiranja, čime postaje medij određenog političkog sadržaja, u opasnosti je da estetizira političko i na taj način ga transformira, preusmjeri i na kraju neutralizira. Politički sadržaj ne može uteći estetičkoj formi. Način na koji film Joker odgovara na ovaj paradoks estetičke forme i političkog sadržaja taj je da on taj paradoks iznosi. Forma ostaje nužno estetička, ali u samom sadržaju događa se sukob

\section{2}

Usp. Damir Smiljanić, »Hermeneutika draži«, u: Damir Smiljanić, Iritacije, Adresa, Novi Sad 2014., str. 5-35.

43

Usp. Wendy Brown, States of Injury. Power and Freedom in Late Modernity, Princeton University Press, Princeton (NJ) 1995.

44

Usp. F. Nietzsche, Zur Genealogie der Moral, str. $361 \mathrm{i} \mathrm{d}$.

45

Usp. W. Brown, States of Injury, str. 67-74.
47

O recepciji i kritici Nietzschea kod Benjamina usp. Renate Reschke, »Barbaren, Kult und Katastrophen. Nietzsche bei Benjamin. Unzusammenhängendes im Zusammenhang gelesen«, u: Renate Reschke, Denkumbrüche mit Nietzsche. Zur anspornenden Verachtung der Zeit, Akademie Verlag, Berlin 2000., str. 88-106.

48

Gernot Böhme, Atmosphäre. Essays zur neuen Ästhetik, Suhrkamp, Frankfurt na Majni 2013., str. 43

46

Usp. W. Benjamin, Das Kunstwerk im Zeitalter seiner technischen Reproduzierbarkeit, str. 53-55. 
estetizacije i politizacije resantimana. On sam odbija bilo kakvu političku identifikaciju, tvrdeći da je potpuno apolitičan, da pokušava nasmijati ljude. Vrsta estetizacije boli kroz koju Arthur Fleck kompenzira bol jesu imaginacije, odnosno psihoze, koje mu omogućavaju nastaviti živjeti. U psihotičnim epizodama, poput one u kojoj Murray Franklin, voditelj i komičar, zauzima mjesto očinske figure i odaje Arthuru priznanje, ili poput one u kojoj imaginira romantičnu ljubav sa susjedom, zbiva se borba volje s realnošću, borba života nauštrb pamćenja. S druge strane, njegov razvoj od Arthura Flecka do Jokera pokazuje put deprivilegiranih prema njihovoj estetizaciji. Čak i konačno priznanje on zavređuje u estetičkoj formi od strane publike, a ne politički. Njegova figura potpuno je na strani estetizacije pa i estetizacije nasilja, dok resantimanska javnost i novi pokret vide u njemu prizivanje nečega novog.

U njegovu odbijanju političke identifikacije kao politike identiteta zasnovane na resantimanu ogleda se radikalnost te pozicije. On nema što izgubiti, kako sam kaže, ne pristaje na jedinu igru u gradu, analogno politikama identiteta, paradoksalno dovodi u pitanje same okvire u kojima su ove igre moguće. Javnost mu pripisuje političku ili čak revolucionarnu ulogu u novom pokretu. Ono što se ovdje iznosi na vidjelo je, s jedne strane, odbijanje liberalnih okvira politike u smislu određene politike identiteta i stavljanje u pitanje samih tih okvira. Stavljanje u pitanje liberalnih okvira politike je perspektiva kako antimodernističkih ili neokonzervativnih tako i radikalno egalitarnih pozicija. U svemu tome vidi se sukob koji je Joker iznio na vidjelo kao i osjećanje koje ga prati.

Privlačnost figure Jokera leži u njegovoj estetizaciji svjetske boli nošene nejednakošću. Nejednakost se stilizira u klasnu nejednakost koja nas dovodi na obod liberalnog okvira unutar kojega pretežno djeluju ne figure resantimana klasne nejednakosti, nego figure resantimana nejednakosti žena, homoseksualaca, različitih manjinskih grupa. Resantiman klasne nejednakosti dovodi u pitanje sam postojeći liberalni okvir i tržišni sistem redistribucije dobara. Figura Jokera na kraju ipak nije revolucionarna figura, nego kroz estetizaciju politike, jedna predrevolucionarna figura. Politizacija estetike prepuštena je novom pokretu, demonstrantima i javnosti, u konačnici - nama.

\title{
Davor Lazić
}

\section{Joker zwischen Ästhetisierung und Politisierung des Ressentiments}

\begin{abstract}
Zusammenfassung
Mit der Arbeit will man die große Popularität des Films Joker von Todd Phillips aus dem Jahr 2019 verstehen. Der Film und die Figur Joker wird im Rahmen der Philosophie, bzw. Ästhetik und Politik des Ressentiments interpretiert. Die Arbeit bietet den Schluss, dass der Film und die Figur Jokers das Gefühl der Ungleichheit als ein in der Welt verbreitetes Gefühl zwischen seiner Ästhetisierung und Politisierung wiederholen.
\end{abstract}

Schlüsselwörter

Joker, Schmerz, Ressentiment, Ästhetisierung, Politisierung 